\title{
О ПРОБЛЕМАХ И ВОЗМОЖНОСТЯХ ТЕХНОЛОГИИ ПОДЗЕМНОЙ дОБЫчИ ЭСТОНСКИХ ФОСФОРИТОВ
}

Приближаются намеченные сроки вовлечения в эксплуатацию Раквереского месторождения. На выделенном для первоочередного освоения участке Кабала-Западный форсированными темпами ведутся работы по завершению детальной разведки и подготовке запасов к утверждению. Одновременно разрешено начать проектирование подземного рудника до утверждения запасов в ГКЗ СССР, на основе имеющихся временных кондиций, без предварительной проверки в натурных условиях системы подземной разработки и технологии выемки руды. Решить неясные вопросы и развеять все имеющиеся сомнения в части горной технологии предполагается в процессе строительства рудника, когда вскроют месторождение и пройдут необходимые горно-капитальные выработки. С этой целью предусматривается создание опережающего опытного участка горных работ. Между тем основные проблемы технологии подземной добычи слишком серьезны и требуют решения на более ранней стадии, а некоторые слабые места предлагаемых в настоящее время технологических решений и возможные последствия от внедрения последних в производство достаточно очевидны, чтобы высказазаться по этому поводу.

Анализ условий эксплуатации эстонских фосфоритных месторождений с различных точек зрения (горногеологической, гидрогеологической, экологической и т. д.) привел к выводу о необходимости подземной выемки без обрушения налегающей толщи пород. Сохранить в целости налегающие над промышленным пластом породы и минимизировать потери полезного ископаемого при выемке можно лишь при системе с закладкой выработанного пространства. Система предлагалась в различных модификациях. Первоначально речь шла о сухой закладке из пород сланцедобычи (такой вариант вошел в технический проект рудника Тоолсе), затем были предложены варианты с искусственными целиками из бетона, между которыми укладываются пустые породы (Петросянц и др., 1981; Дегтярев, Галкин, 1985). Далее следовало предложение о применении в будущих фосфоритных рудниках Эстонии бесцементной твердеющей закладки на основе сланцевой золы (вяжущего) и флотохвостов обогащения фосфорита (Пязок, 1983). Проводимые в настоящее время исследования показывают перспективность последнего направления.

Система разработки с твердеющей закладкой может иметь, как известно, различные конструктивные варианты, схемы некоторых из них в очень упрощенном виде показаны на рисунке.

Первый вариант представляет камерную выемку на всю мощность залежи с последующей закладкой выработанного пространства твердеющей смесью. Второй вариант - двухстадийная камерная выемка с искусственными ленточными целиками из твердеющего материала. Руда между искусственными целиками вынимается во вторую стадию 
горных работ, а образовавшиеся в результате выемки камеры закладываются либо пустыми породами, либо специальными закладочными смесями - как твердеющими, так и обычными. Последний, третий вариант представляет слоевую выемку в нисходящем порядке со сплошной твердеющей закладкой, образующей искусственную кровлю для выемки нижележащего слоя.

Производительность труда забойного рабочего и экономические показатели системы разработки с твердеющей закладкой существенно зависят от технологичности применяемого варианта системы. В этом смысле наиболее эффективными являются камерные варианты (рисунок, 1,2$)$, имеющие малый удельный объем подготовительно-нарезных работ в панели, большие объемы единовременно закладываемых пустот, что позволяет наладить механизированный и автоматизированный процесс закладки. Второй вариант уступает первому в вопросах прочности искусственного массива и поддержания кровли, но зато характеризуется большей организационной гибкостью - малой взаимосвязанностью смежных процессов, возможностями управления шириной фронта горных работ и регулирования производительности блока по добыче, а также некоторыми другими преимуществами.

Возможность применения того или иного варианта системы разработки диктуется горногеологическими условиями месторождения. На рассматриваемом Раквереском месторождении можно выделить всего три горно-геологических фактора, которые накладывают жесткие ограничения на технологию, диктуют возможности применения только того или иного конкретного варианта и в общей совокупности создают технико-технологические проблемы подземной эксплуатации месторождения.

Первый из таких факторов - наличие над промышленным пластом слабосцементированных глауконитовых песчаников, образующих неустойчивую и склонную к самообрушению непосредственную кровлю пласта. В принципе возможны следующие способы разработки: вынимать промышленный пласт под глауконитом; селективно извлекать глауконит как пустую породу и размещать в камерных выработках шахты, затем разрабатывать промышленный пласт; применять валовую выемку фосфорита с глауконитом и затем обогащать полученную горную массу.

Выемка промышленного пласта под глауконитом возможна в виде системы слоевой выемки (рисунок, 3), имеющей наихудшие экономические показатели. Сейчас ГИГХСом рекомендуется селективная технология выемки глауконита отдельным уступом в очистной камере. Селективная технология накладывает свои ограничения на выбор варианта системы разработқи: она возможна лишь при двухстадийном камерном варианте, когда имеются вторичные камеры между искусственными целиками, способные вместить глауконит. Применение камерной системы со сплошной закладкой (рисунок, 1) становится невоз-

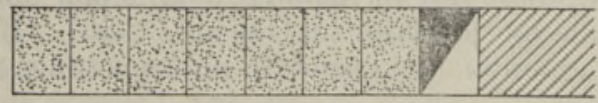

2
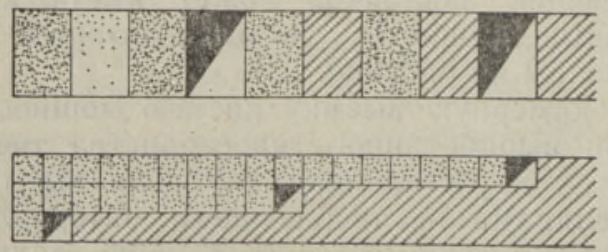

Принципиальные схемы вариантов снстемы разработки с твердеющей заходкой (вертикальный разрез по промышленному пласту). Пояснения в гексте. 
можным из-за технологических и организационных сложностей размещения отбитого глауконита. Простое складирование его под закладочным материалом в камере недопустимо ввиду резкого ухудшения устойчивости получаемого искусственного массива (возникает опасность оползней). Включение глауконита в состав материала твердеющей закладки путем слияния его потока с напорной закладочной артерией на подземном горизонте технологически неосуществимо.

Селективная выемка глауконита усложняет и удорожает горные работы. С учетом этого обстоятельства нами был предложен вариант валовой (совместной) выемки фосфорита с глауконитом (Детковский и др., 1985). Расчеты подтверждают экономическую целесообразность его применения.

Важным горногеологическим фактором, связанным с проблемами технологии отбойки, является высокая абразивность материала промышленного пласта, содержащего очень много кварца. ГИГХС рекомендует использовать на выемке фосфорита механическую отбойку, ссылаясь на положительные результаты испытания пород Маарду и Тооле (Дегтярев, Галкин, 1985). К сожалению, эти выводы мало увязываются с некоторыми фактами. В начале $60-x$ годов на том же самом месторождении Маарду проводились промышленные испытания по отбойке руды современным в ту пору узкозахватным выемочным комбайном IK-52M. Испытания окончились полной неудачей по причине абразивности руды. Таким образом, возможности механизированной отбойки на фосфоритных месторождениях находятся под большим сомнением. Очевидно, наиболее реальным останется традиционный буровзрывной способ отбойки.

И наконец последний из факторов, создающий наиболее серьезные препятствия подземному способу эксплуатации фосфоритных месторождений Әстонии, - малая устойчивость пород промышленного пласта. По данным кернов разведочных скважин породы фосфоритного пласта представляют собой рыхлый слабосцементированный песок, имеющей лишь отдельные твердые включения. Слабая сцементированность пород, прежде всего, будет затруднять перемещение колесного горношахтного оборудования. Почву пройденных в фосфоритном пласте транспортных горных выработок придется мостить плитами. Главная же опасность, исходящая из неустойчивости пород, кроется в весьма вероятных отслоениях и обрушениях пород по вертикальным обнажениям массива. Обрушения были довольно типичным явлением на подземных работах Маардуского рудника при мощности пласта около 1 м. На участке Кабала-Западный мощность пласта местами достигает 12 м, а требующиеся при камерных системах разработки площади вертикальных обнажений могут значительно превышать $1000 \mathrm{~m}^{2}$. Закрепить вертикальные обнажения в таких камерах не представляется возможным. Не следует забывать и о сейсмическом воздействии на обнаженный массив взрывных работ в камерах при выемке руды. Все это в совокупности предопределяет большую угрозу безопасности горных работ.

Не исключено, что из-за слабой устойчивости массива придется отказаться от камерных вариантов системы разработки с закладкой. Тогда остается единственный выход - применить слоевой способ выемки со сплошной твердеющей закладкой (рисунок, 3). Это будет, по всей видимости, система разработки длинными столбами с узкими поперечными заходками ограниченного сечения. Первый слой придется вынимать под глауконитом (иной возможности нет) с использованием усиленной крепи ограждающего типа. После выемки руды из каждой заходки производится ее закладка твердеющей смесью. Выемка руды из каждой следующей заходки возможна лишь после окончательного твердения 
закладочного массива в предыдущей. Нижележащие слои вынимаются в аналогичном порядке, в лучшем случае лишь без применения усиленной крепи выработок. Промышленный пласт на участке Кабала-Западный может быть разделен на 3-5 слоев высотой по 2-3 м.

Система слоевой выемки характеризуется ограниченностью рабочего пространства, деконцентрацией горных работ, высокой трудоемкостью закладки и является в целом весьма сложным в организационном смысле, трудоемким и дорогостоящим способом эксплуатации месторождения. Имеющиеся на сегодняшний день экономические оценки возможных показателей подземной добычи фосфоритов Эстонии относятся к камерным вариантам системы с закладкой, следовательно, основаны на самых оптимистических предпосылках. В случае перехода на слоевую выемку они резко изменятся в худшую сторону. Например, по данным ГИГХСа производительность труда забойного рабочего уменьшится в 2,5 раза (Дегтярев, Галкин, 1985). По ориентировочным расчетам эксплуатационные затраты возрастут примерно во столько же раз. Значительно снизятся интенсивность эксплуатации месторождения и возможная производственная мощность рудника. Естественным в таких условиях является возникновение вопроса об экономической целесообразности допущения подобных затрат и о народнохозяйственной приемлемости подземного способа эксплуатации месторождения.

Подводя итог краткому анализу проблем и возможностей подземной добычи фосфорита, можно сформулировать следующие основные выводы.

1. Подземная добыча допустима при условии сохранения в целости налегающей над месторождением толщи пород. Соблюдение этого условия является реальным лишь при системе разработки с закладкой, однако возможность применения эффективных высокопроизводительных камерных вариантов этой системы экспериментально не проверена и находится под сомнением, главным образом из-за слабой устойчивости пород фосфоритного пласта.

2. Принятое в настоящее время решение о проектировании крупного по своим масштабам рудника Кабала без предварительной экспериментальной проверки параметров системы подземных горных работ представляется чрезвычайно рискованным шагом. По существу это означает, что проектирование будет вестись под недостоверную технологию. А ведь речь идет об основном технологическом процессе горнодобывающего предприятия - выемке полезного ископаемого из недр.

3. Экспериментальная проверка технологии подземной добычи в необходимом для этого объеме должна быть выполнена до проектирования рудника. Намечаемое же создание опережающего экспериментального участка горных работ в составе строящегося предприятия слишком запоздалое мероприятие для исправления допущенных при проектировании просчетов. Не исключено, что результаты опытных работ дадут почву для коренной переоценки приемлемости подземного способа эксплуатации месторождения. Однако такой вывод, полученный после вложения миллионов рублей в строительство рудника, будет весьма слабым утешением.

\section{ЛИ ТЕ Р А Т Р Р}

Петросянц Э. В., Галкин В. А., Бровченко И. Н. Технологические решения подземной разработки месторождення фосфорнтов Тоолсе. - В кн.: Совершенствование подземной разработки месторождений горнохимнческого сырья (Тр. ГИГХСа, вып. 51). М., 1981, 6-10.

Дегтярев B. A., Галкин B. A. Перспективы подземной разработки месторождений Прибалтийского фосфоритоносного бассейна. - В кн.: Проблемы развития и рационального нспользования ресурсов Прибалтийского фосфоритоносного бассейна (Тр. ГИГХСа, вып. 63). М., 1985, $90-96$. 
Пязок Р. А. О рациональной организации освоения комплексных сланцефосфоритных месторождений Раквереского района Эстонской ССР. - Горючие сланщы (информ. серия І ЭстНИИНТИ), 1983, № 2, 6-9.

Детковский С., Петерселль В., Пязок Р. Об экономической целесообразности включения глауконитовых песчаников в контур выемки фосфоритных залежей Эстонии подземным способом. - Изв. АН ЭССР, Геол., 1985, 34, № 3, 77-84.

Институт экономики

Академии наук Эстонской ССР
Поступила в редакцию 28/IV 1986

R. PÄSOK

\section{EESTI FOSFORIIDI ALLMAAKAEVANDAMISE TEHNOLOOGIA PROBLEEME JA VOIMALUSI}

Artiklis on analüüsitud fosforiidileiukoha allmaakaevandamist koos kaeveōõnte täitmisega ja sellega seotud tehnoloogilisi probleeme. Avaldatakse kahtlust, kas fosforiidikihi ebapüsivuse tōttu on vōimalik kasutada nimetatud kaevandamisviisi kõrgtootlikke kambervariante. Tõstatatakse küsimus katsekaevandamise vajalikkusest enne ettevōtte projekteerimist.

\section{R. $P A \breve{S O K}$}

\section{ON PROBLEMS AND POSSIBILITIES OF THE TECHNOLOGY OF UNDERGROUND MINING OF ESTONIAN PHOSPHORITES}

Technological problems of the underground exploitation of phosphorite deposits by the cut-and-fill techniques are analyzed in the paper. The author is not sure of the possibilities of using high-productive stopping methods of the named techniques because of the unstability of the ore body rocks. Tests of the methods of underground mining must be performed before projecting a mine. 